\title{
A Rapid Polymerase Chain Reaction-Based Assay Characterizing Rhizosphere Populations of 2,4-Diacetylphloroglucinol-Producing Bacteria
}

\author{
Brian B. McSpadden Gardener, Dmitri V. Mavrodi, Linda S. Thomashow, and David M. Weller
}

\begin{abstract}
First, third, and fourth authors: U.S. Department of Agriculture, Agricultural Research Service, Root Disease and Biological Control Research Unit, Washington State University, Pullman 99164; and second author; Washington State University, Department of Plant Pathology, Pullman 99164.

Current address of B. McSpadden Gardener: Department of Plant Pathology, 1680 Madison Ave., Ohio State University, OARDC, Wooster 44691.
\end{abstract}

Accepted for publication 3 October 2000.

\begin{abstract}
McSpadden Gardener, B. B., Mavrodi, D. V., Thomashow, L. S., and Weller, D. M. 2001. A rapid polymerase chain reaction-based assay characterizing rhizosphere populations of 2,4-diacetylphloroglucinolproducing bacteria. Phytopathology 91:44-54.

Pseudomonas species that produce 2,4-diacetylphloroglucinol $(2,4-$ DAPG) play a significant role in the suppression of fungal root pathogens in the rhizosphere of crop plants. To characterize the abundance and diversity of these functionally important bacterial populations, we developed a rapid polymerase chain reaction (PCR)-based assay targeting phlD, an essential gene in the phloroglucinol biosynthetic pathway. The phlD gene is predicted to encode a polyketide synthase that synthesizes monoacetylphloroglucinol, the immediate precursor to 2,4-DAPG. A major portion of the phlD open reading frame was cloned and sequenced from

five genotypically distinct strains, and the sequences were screened for conserved regions that could be used as gene-specific priming sites for PCR amplification. Several new phlD-specific primers were designed and evaluated. Using the primers B2BF and BPR4, we developed a PCR-based assay that was robust enough to amplify the target gene from a diverse set of 2,4-DAPG producers and sensitive enough to detect as few as log 2.4 cells per sample when combined with enrichment from a selective medium. Restriction fragment length polymorphism analysis of the amplified phlD sequence allows for the direct determination of the genotype of the most abundant 2,4-DAPG producers in a sample. The method described was useful for characterizing both inoculant and indigenous $p h l D^{+}$ pseudomonads inhabiting the rhizosphere of crop plants. The ability to rapidly characterize populations of 2,4-DAPG-producers will greatly enhance our understanding of their role in the suppression of root diseases.
\end{abstract}

Fluorescent Pseudomonas spp. have been studied intensively because of their abundance in the rhizosphere and their abilities to promote plant growth, either by directly stimulating the plant or by suppressing fungal root pathogens (6). Pseudomonads that produce the antibiotic 2,4-diacetylphloroglucinol (2,4-DAPG) inhibit a broad spectrum of plant pathogenic fungi $(7,12,15,30$, $38,39)$ and control a variety of root and seedling diseases $(9,15$, 36,39). Three lines of evidence substantiate the importance of 2,4DAPG production in biological control. First, mutations in the biosynthetic pathway resulted in reduced biocontrol activity $(9,15,30,44)$. Second, the population size of $2,4-D A P G$ producers in the rhizosphere correlated with disease suppressiveness of the soil and in situ antibiotic production $(34,36,37)$. Third, diverse 2,4-DAPG-producing Pseudomonas spp. have been isolated from the rhizosphere of various crop plants $(14,28,33,35)$, and their roles in promoting plant growth and inhibiting root diseases are the subjects of ongoing investigations worldwide.

The genes required for the biosynthesis of 2,4-DAPG have been cloned and sequenced, and a biosynthetic pathway has been proposed in which the phlD gene functions to synthesize monoacetylphloroglucinol from acetoacetyl-CoA (4). The phlD gene is notable because its protein product shares significant homology with plant chalcone and stilbene synthases, a structurally distinct

Corresponding author: B. McSpadden Gardener

E-mail address: mcspadde@mail.wsu.edu

Publication no. P-2000-1106-01R

This article is in the public domain and not copyrightable. It may be freely reprinted with customary crediting of the source. The American Phytopathological Society, 2001. class of polyketide synthases that appear to be rare in bacteria (4). The limited distribution of phlD among microbes makes it an ideal marker gene for 2,4-DAPG-producing Pseudomonas spp. In our laboratory, primers and probes targeting phlD have been used in a colony hybridization protocol to identify and isolate 2,4DAPG-producing pseudomonads in the rhizosphere (37). This approach has been used successfully to correlate the abundance of 2,4-DAPG-producing Pseudomonas spp. with the natural suppression of take-all disease caused by Gaeumannomyces graminis var. tritici known as take-all decline $(36,37)$. However, the colony hybridization protocol was inadequate for detailed studies of the population dynamics of these 2,4-DAPG producers that require rapid processing of large numbers of samples. Therefore, we set out to develop a polymerase chain reaction (PCR)-based assay that could be used to rapidly characterize the abundance and diversity of 2,4-DAPG-producing Pseudomonas spp.

The PCR has been used extensively to detect and characterize microbial populations $(17,23,32)$. Numerous PCR-based assays have been developed to detect specific populations of bacteria and fungi of interest to plant pathologists, to characterize the genotypic diversity of plant pathogens, their antagonists, and other plantassociated microbes $(8,13,18,28,46)$. There are, however, some notable difficulties in using PCR to study the abundance and diversity of microbial populations inhabiting complex environments such as the rhizosphere (17,32). Most published assays require the isolation of relatively pure template DNA from the environment, a process that can be difficult and labor intensive. Moreover, genotypic characterization often requires isolating the microorganisms under investigation, which is not always possible. Furthermore, the extraordinary diversity of microbial populations inhabiting natural environments (31) and lack of information on 
the sequences present there may often preclude the development of adequately specific primers. Despite these difficulties, direct PCR-based detection of distinct microbial species in the rhizosphere has been achieved (17).

Our objectives were to develop a rapid PCR-based assay that specifically targets an important class of biocontrol bacteria, phlD ${ }^{+}$Pseudomonas spp. Our approach is unique because it can be used to rapidly enumerate and directly characterize phlD populations at the subspecies level. Additionally, the detailed methodology described here can be used as a model to develop similar assays for other microbial populations associated with the development or control of plant diseases.

\section{MATERIALS AND METHODS}

Bacterial cultures and maintenance. All chemicals were obtained from Sigma Chemical Co., St. Louis, unless noted otherwise. Strains were cultured on $1 / 3 \times$ King's medium B $(1 / 3 \times$ $\mathrm{KMB}$ ) consisting of $6.7 \mathrm{~g}$ of proteose peptone (Difco Laboratories, Detroit), $0.4 \mathrm{~g}$ of $\mathrm{KH}_{2} \mathrm{PO}_{4}, 0.5 \mathrm{~g}$ of $\mathrm{MgSO}_{4}-7 \mathrm{H}_{2} \mathrm{O}$, and $3.3 \mathrm{ml}$ of glycerol per liter at $\mathrm{pH}$ 7.0. Strains also were cultured on a Pseudomonas selective medium based on the Simon-Ridge medium (41), $13 \times \mathrm{KMB}^{+++}$, consisting of $1 / 3 \times \mathrm{KMB}$ supplemented with ampicillin $(40 \mu \mathrm{g} / \mathrm{ml})$, chloramphenicol $(13 \mu \mathrm{g} / \mathrm{ml})$, and cycloheximide $(100 \mu \mathrm{g} / \mathrm{ml})$. The medium $1 / 3 \times \mathrm{KMBRif}^{+}$consisted of $1 / 3 \times \mathrm{KMB}$ supplemented with rifampicin $(50 \mu \mathrm{g} / \mathrm{ml})$ and cycloheximide $(100 \mu \mathrm{g} / \mathrm{ml})$. To solidify these media, agar was added at $15 \mathrm{~g} / \mathrm{liter}$.

Nineteen $p h l D^{+}$strains, representing the 17 distinct genotypes of 2,4-DAPG-producing Pseudomonas spp. defined previously (28), were used: CHA0 (42), Pf-5 (30), Q2-87 (12), F113 (38), Q8r1-96 (36), 1M1-96 (35), OC4-1, FFL1R9, Q2-2, JMP6, JMP7, FFL1R18, CV1-1, FTAD1R36, FFL1R22, W2-6, W4-4, D27B1, and HT5-1. Strain 1M1-96 was genotypically identical to W4-4 by repetitive sequence-based PCR using the BOXA1R primer (BOX-PCR) (23) (B. McSpadden Gardener and D. Weller, unpublished data). A rifampicin-resistant isolate of W2-6, called W2-6R, was obtained by plating on $1 / 3 \times \mathrm{KMBRif}^{+}$agar. $P$. fluorescens strain 2-79 (45), which does not produce 2,4-DAPG, was used as a negative control in the PCR assays. Frozen stock cultures of all strains were stored in $1 / 3 \times \mathrm{KMB}$ plus $18 \%$ glycerol at $-80^{\circ} \mathrm{C}$.

Cloning and sequencing of phlD gene fragments. Genomic DNA was isolated by a cetyltrimethylammoniumbromide (CTAB)-based miniprep procedure (2). A 745-bp fragment of the 1,001-bp phlD gene was amplified by PCR with the oligonucleotide primers $\mathrm{Phl} 2 \mathrm{a}$ and $\mathrm{Phl} 2 \mathrm{~b}$ (37). Amplification was carried out in a $25-\mu \mathrm{l}$ reaction mixture containing $20 \mathrm{ng}$ of genomic DNA, $1 \times T a q$ DNA polymerase buffer (Promega Corp., Madison, WI), $1.5 \mathrm{mM} \mathrm{MgCl}_{2}, 5.0 \%$ dimethyl sulfoxide, $200 \mu \mathrm{M}$ each of dGTP, dATP, dCTP, and dTTP (Perkin-Elmer, Norwalk, CT), 20 pmoles of each primer, and 1.2 units of Taq DNA polymerase (Promega). Amplifications were performed with a thermal cycler (PTC-200, MJ Research, Watertown, MA). The cycling program included a 45-s initial denaturation at $94^{\circ} \mathrm{C}$ followed by 35 cycles at $94^{\circ} \mathrm{C}$ for $35 \mathrm{~s}, 53^{\circ} \mathrm{C}$ for $30 \mathrm{~s}$, and $72^{\circ} \mathrm{C}$ for $45 \mathrm{~s}$, followed by a $4^{\circ} \mathrm{C}$ soak. Amplification products were separated on a $0.7 \%$ agarose gel, extracted with a gel extraction kit (QIAEX II, Qiagen, Valencia, CA), and ligated into pGEM-T Easy vector (Promega) according to the manufacturer's protocol. Plasmids were introduced into electrocompetent cells of Escherichia coli strain JM109 (Gene Pulser II, Bio-Rad Laboratories, Hercules, CA) according to Ausubel et al. (2) at settings of $25 \mathrm{uF}$ for the capacitor, $200 \Omega$ resistance, and an electric field of $1.8 \mathrm{kV} / \mathrm{cm}$. Plasmid DNA was purified from transformed cells by standard methods (2) and used for sequencing.

The nucleotide sequence of cloned inserts were determined by the ABI Prism Dye Terminator Cycle Sequencing Kit (Perkin-
Elmer) according to the manufacturer's instructions. Sequence data were compiled and analyzed with the Omiga 1.1.3 software package (Oxford Molecular Ltd., Oxford, U.K.). Database searches for similar nucleotide and protein sequences were carried out with the BLAST network server at the National Center for Biotechnology Information (NCBI) (1). The cloned sequences corresponded to a major portion of the phlD gene from CHA0, Pf5, Q8r1-96, and 1M1-96, and were deposited in GenBank as Accession Numbers AF214456, AF214457, AF207693, and AF207692, respectively. The fifth sequence used to design the new gene-specific primers represented the corresponding portion of the phlD gene isolated from strain Q2-87 (4) (GenBank Accession No. U41818).

Design of primers. Multiple sequence alignments of the phlD sequences were built with Clustal X (43). Regions of the alignment were scanned manually for areas with high sequence identity that could be used as priming sites for PCR amplification. Potential priming sites were selected based on the following criteria for the annealing primer: (i) $\geq 87 \%$ identity of the primer to all cloned sequences, (ii) a $\mathrm{C}$ or $\mathrm{G}$ in the terminal $3^{\prime}$ position, (iii) a $T_{m} \geq$ $55^{\circ} \mathrm{C}$, (iv) no hairpin loops predicted by Oligo 4.0 (Molecular Biology Insights Inc., Cascade, CO), and (v) a priming site $\geq 350 \mathrm{bp}$ distant from that of the nearest complementary primer.

Preparation of bacterial templates. Colonies ( $\leq 4$ days old) grown on $1 / 3 \times \mathrm{KMB}^{+++}$agar were suspended in $1 \mathrm{ml}$ of $1 / 3 \times$ KMB broth, pelleted by centrifugation for $15 \mathrm{~s}$, and resuspended in $0.5 \mathrm{ml}$ of broth. The concentration of washed cells was adjusted with broth to $4 \times 10^{9}$ cells per $\mathrm{ml}$ with a microplate spectrophotometer (Dynatech MR5000, Dynatech Laboratories, Burlington, MA). Serial dilutions were made in 96-well microtiter dishes with liquid $1 / 3 \times \mathrm{KMB}$ broth as the dilutant.

Whole-cell templates were prepared to test the specificity and sensitivity of the PCR-based assay. To test the specificity of the primers, all test strains were adjusted to a constant concentration (approximately $10^{9}$ cells per $\mathrm{ml}$ ). To test the sensitivity of the assay to detect $p h l D^{+}$strains in a background of $p h l D^{-}$bacteria, two different types of template mixtures were prepared. The first mixture consisted of a fourfold serial dilution of strain Q8r1-96 or Pf-5 $\left(2 \times 10^{8}\right.$ down to $1 \times 10^{4}$ cells per $\left.\mathrm{ml}\right)$ in a constant concentration of the negative control strain 2-79 $\left(2 \times 10^{8}\right.$ cells per ml). The second mixture consisted of a fourfold serial dilution of a 24:1 mixture of strain 2-79 and either strain Q8r1-96 or Pf-5 (2× $10^{8}$ down to $1 \times 10^{4}$ cells per $\mathrm{ml}$ ). Dilutions were initially frozen at $-80^{\circ} \mathrm{C}$ for a minimum of $1 \mathrm{~h}$, and then transferred to a $-20^{\circ} \mathrm{C}$ freezer for storage.

Rhizosphere sampling. Wheat (Triticum aestivum L. cv. Penawawa) seeds were coated with a $1 \%$ methylcellulose solution $(0.12 \mathrm{ml} / \mathrm{g}$ of seed) with or without the inoculant strain $\mathrm{W} 2-6 \mathrm{R}$ at a rate of $10^{4}$ cells per seed, and allowed to air dry in a laminar flow hood. Seeds were hand sown within $48 \mathrm{~h}$ into separate microplots ( $4 \mathrm{ft}$ [4 rows, 12-in spacing] $\times 6 \mathrm{ft}$ ) at a rate of approximately $112 \mathrm{~kg} / \mathrm{ha}$ (7 g per 6-ft row) at the Washington State University Dryland Research Station, Lind, WA. Moisture was provided by weekly sprinkler irrigation. At 4 to 19 weeks after planting, the top $15 \mathrm{~cm}$ of the root systems of whole plants were carefully dug up with a shovel and placed in plastic bags for transport to the laboratory. Samples were placed in a cold room $\left(8^{\circ} \mathrm{C}\right)$ within $3 \mathrm{~h}$ of sampling and stored for no more than 3 days prior to processing.

For processing, rhizospheres from individual plants were processed separately. The intact portion of each root system (50 to $2,000 \mathrm{mg}$ washed weight) was separated manually from loosely adhering soil, and cut off from the shoot with a clean razor blade. Individual rhizosphere samples were placed in a 15-mm-diameter test tube with $7.5 \mathrm{ml}$ of sterile distilled water $(4,7$, and 11 weeks postplanting) or in a 30 -mm-diameter test tube with $21.5 \mathrm{ml}$ of sterile distilled water (14 and 19 weeks postplanting). Bacteria and adhering soil $(\leq 30 \%$ by weight $)$ were dislodged from the roots 
by vortexing four times, $15 \mathrm{~s}$ each time, followed by a 1-min incubation in a sonication bath (Bransonic 521; Branson, Shelton, CT). One-hundred microliters of each sample was serially diluted in a 96-well microtiter plate (Costar, Corning, NY) prefilled with $200 \mu \mathrm{l}$ of sterile distilled water in each well. Fifty microliters of each dilution was then transferred into other 96-well plates containing $200 \mu \mathrm{l}$ of either $1 / 3 \times \mathrm{KMB}^{+++}$or $1 / 3 \times \mathrm{KMBRif}^{+}$. The plates were incubated at room temperature in the dark for $48 \pm$ $4 \mathrm{~h}$. Bacterial growth was assayed spectrophotometrically, with an $\mathrm{OD}_{600 \mathrm{~nm}} \geq 0.05$ being scored as positive. Replica plates were made by transferring $100 \mu \mathrm{l}$ of each culture into $100 \mu \mathrm{l}$ of $35 \%$ glycerol, and these plates were stored at $-80^{\circ} \mathrm{C}$. Cultures were frozen at $-80^{\circ} \mathrm{C}$ for a minimum of $1 \mathrm{~h}$, and then transferred to a $-20^{\circ} \mathrm{C}$ freezer for storage until needed for PCR amplification.

PCR amplifications and restriction fragment length polymorphism analyses. Portions of the phlD gene were amplified by the newly designed primers (Table 1). Amplifications were carried out in $25-\mu \mathrm{l}$ reaction mixtures containing $2.5 \mu \mathrm{l}$ of whole cell template, $1 \times$ Taq DNA polymerase buffer (Promega), $1.5 \mathrm{mM} \mathrm{MgCl}_{2}$, $200 \mu \mathrm{M}$ each of dGTP, dATP, dCTP, and dTTP (Gibco BRL, Bethesda, MD), 25 pmoles of each primer, and 1.5 units of Taq DNA polymerase (Promega). Amplifications were performed in a thermal cycler (MJ Research) with the following cycling conditions: $95^{\circ} \mathrm{C}$ for $3 \mathrm{~min}, 35 \times 94^{\circ} \mathrm{C}$ for $1 \mathrm{~min}, 60^{\circ} \mathrm{C}$ for $1 \mathrm{~min}$, and $72^{\circ} \mathrm{C}$ for $1 \mathrm{~min}, 72^{\circ} \mathrm{C}$ for $5 \mathrm{~min}$, followed by a $4^{\circ} \mathrm{C}$ soak and $-20^{\circ} \mathrm{C}$ storage. After amplification, $8 \mu \mathrm{l}$ of each reaction was loaded onto $1.5 \%$ agarose gels in $0.5 \times$ Tris-borate-EDTA (TBE) and electrophoresed for 2 to $3 \mathrm{~h}$ at $125 \mathrm{~V}$.

For restriction fragment length polymorphism (RFLP) analyses, $8 \mu \mathrm{l}$ of a PCR reaction was digested in a total volume of $30 \mu \mathrm{l}$ of $1 \times$ sample buffer with 10 units of a single restriction enzyme (New England Biolabs Inc., Beverly, MA). Reactions were incubated at either $37^{\circ} \mathrm{C}$ (HaeIII, HinfI, MspI, RsaI, and Sau96I) or $60^{\circ} \mathrm{C}(\mathrm{Taq} \mathrm{I})$ for 2 to $4 \mathrm{~h}$ and stored at $-20^{\circ} \mathrm{C}$. Digestion products were separated on $2 \%$ agarose gels in $0.5 \times \mathrm{TBE}$ for 2 to $3 \mathrm{~h}$ at $140 \mathrm{~V}$. Banding patterns were visualized by ethidium bromide staining and scored by comparison to a 100-bp DNA ladder. Gel images were taken and stored as tiff files with a digital imaging system (Kodak DC120; Kodak, Rochester, NY).

Statistics. All statistics were calculated according to well established parametric and nonparametric procedures $(27,40)$ with the assistance of the Data Analysis package bundled with Microsoft Excel 97 (Microsoft Corp., Redmond, WA).

\section{RESULTS}

Design of phlD-specific primers. Clustal $\mathrm{X}$ was used to align the $p h l D$ sequences obtained from five genotypically distinct 2,4DAPG-producing Pseudomonas spp. strains CHA0, Pf-5, Q8r196, 1M1-96, and Q2-87 (Fig. 1). The gene sequences were 71\% identical across the 705 nucleotides determined from all five of the amplified fragments. Interestingly, the sequences from $\mathrm{CHA} 0$ and Pf-5, >98\% identical to each other, were quite distinct from the sequences obtained from strains Q2-87, Q8r1-96, and 1M1-96. Several regions of the gene were identified as having very high sequence identity across all five genotypes. These regions were evaluated systematically for suitable priming sites.

Using the criteria described above, six new phlD-specific primers were designed (Table 1). Four of the primers, BPF2, BPF3, BPR3, and BPR4, met all of the design criteria. Two other new primers, B2BF and BPR2, met four of the five criteria. Primer B2BF was designed by adding four nucleotides to the $5^{\prime}$ end and one nucleotide to the $3^{\prime}$ end of Phl2b using the known sequence from strain Q2-87. This was done to amplify as much of the gene as possible, given that there were few potential priming sites at the $5^{\prime}$ end of the gene. Primer BPR2 was designed to specifically amplify sequences belonging to the amplified rDNA restriction analysis (ARDRA) group B (28), which was reported to have the largest geographic distribution, and therefore would not be expected to amplify phlD sequences from $\mathrm{CHA} 0$ and $\mathrm{Pf}-5$ (ARDRA group A) (28).

The primer sequences listed in Table 1 were compared with the NCBI nonredundant nucleotide database (release 21 April 2000) by using BLAST 2.0.12 (1). All of the newly defined primers scored fewer matches than previously defined primers Phl2A and $\mathrm{Phl} 2 \mathrm{~B}$ (Table 2). The sequences of Phl2A and Phl2B shared $\geq 75 \%$ identity in their entirety, along with $\geq 60 \%$ identity at their $3^{\prime}$ ends, with several other sequences present in a variety of taxa. In contrast, none of the new primers showed a similar level of identity with any known prokaryotic sequences, and only B2BF, BPF3, and BPR3 shared a similar level of identity with any known eukaryotic sequences (Table 2). Only BPF3 shared substantial identity $(67 \%)$ with any known microbial sequences including one or more from $P$. putida, $P$. aeruginosa, Acinetobacter spp., and $B a$ cillus spp. Thus, the new primers were predicted to be much more effective as gene-specific primers than Phl2a and Phl2b.

In vitro detection of 2,4-DAPG-producing Pseudomonas spp. with gene-specific primers. The six newly designed primers were tested in different combinations for their utility to amplify phlD sequences from several distinct genotypes (Fig. 2). The strains selected represented six different genotypes and three different ARDRA groups (28). For each combination of primers, DNA products of the expected size were amplified from the majority of test strains. However, not all combinations were able to specifically amplify phlD from all test strains. Most combinations worked well on Q2-87, Q8r1-96, 1M1-96, and F113 (ARDRA groups $\mathrm{B}$ and $\mathrm{C}$ ). Notably, reactions with BPR2 in combination with B2BF or BPF2 specifically amplified products of the expected size from these closely related genotypes, but not from the more distantly related strains CHA0 and Pf-5 (ARDRA group A). In general, the target sequences were not amplified efficiently from CHA0 and Pf-5 (Fig. 2). This indicates that the reaction conditions and accessibility of the primers to the target sequences were suboptimal for these two templates. Interestingly, reactions that included BPF3 contained several amplification products, indicating that this primer annealed to a number of nonspecific tem-

TABLE 1. Gene-specific primers targeting phlD

\begin{tabular}{llcc}
\hline Primer & Sequence & Position $^{\mathrm{a}}$ & $T_{m}\left({ }^{\circ} \mathrm{C}\right)^{\mathrm{b}}$ \\
\hline Phl2 $\mathrm{b}^{\mathrm{c}}$ & ACC GCA GCA TCG TGT ATG AG & $2660-2641$ & 53.5 \\
Phl2 $\mathrm{a}^{\mathrm{c}}$ & GAG GAC GTC GAA GAC CAC CA & $1915-1934$ & $2664-2640$ \\
B2BF & ACC CAC CGC AGC ATC GTT TAT GAG C & $2550-2527$ & 64.7 \\
BPF2 & ACA TCG TGC ACC GGT TTC ATG ATG & $2510-2487$ & 65.6 \\
BPF3 & ACT TGA TCA ATG ACC TGG GCC TGC & $2067-2091$ & 62.4 \\
BPR2 & GAG CGC AAT GTT GAT TGA AGG TCT C & $2114-2137$ & 62.1 \\
BPR3 & GGT GCG ACA TCT TTA ATG GAG TTC & $2036-2061$ & 55.8 \\
BPR4 & CCG CCG GTA TGG AAG ATG AAA AAG TC & 63.4 \\
\hline
\end{tabular}

a Nucleotide position to which the primers correspond in the $p h l$ locus from Q2-87 (GenBank Accession No. U41818). In this locus, the coding sequence of the phlD gene extends ( $5^{\prime}$ to $3^{\prime}$ ) from position 2859-1810.

${ }^{\mathrm{b}}$ Melting temperature calculated with Oligo 4.0 (Molecular Biology Insights, Cascade, CO).

${ }^{c}$ These primers were described previously (37). 
plate sequences in all of the pseudomonad genomes tested (Fig. 2). Only two primer sets, BPF2 with BPR4 and B2BF with BPR4, were useful for amplifying phlD sequences from all six test strains under the high stringency conditions described. The latter set was chosen for further testing because it amplified a greater portion of the phlD gene (629 versus $535 \mathrm{bp}$ ). Most significantly, these two primers were able to amplify phlD from a collection of 2,4DAPG-producing pseudomonads representing all 13 genotypes recently defined by BOX-PCR (28) (Fig. 3). Therefore, we concluded that the primers would be suitable for detecting a wide

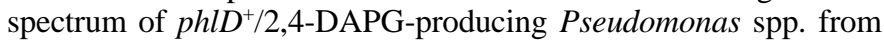
natural environments.

BPF2

80

100

110

120

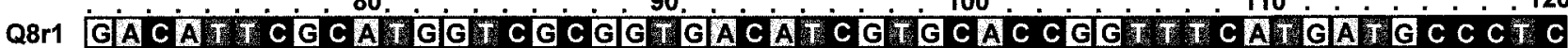

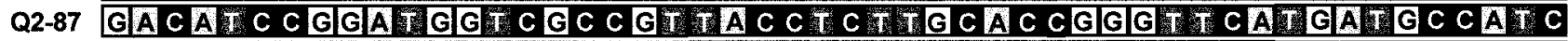

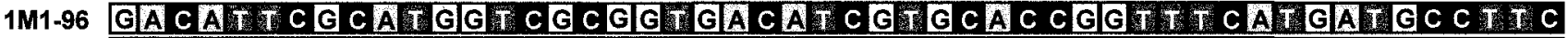

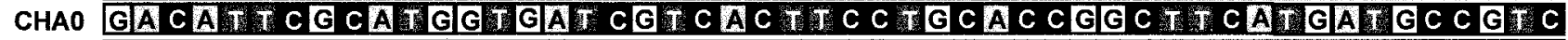

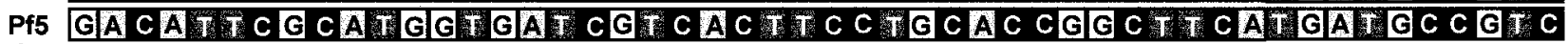
Identity

\section{BPF3}

\section{0 \\ 140 \\ 150 \\ 160}

170

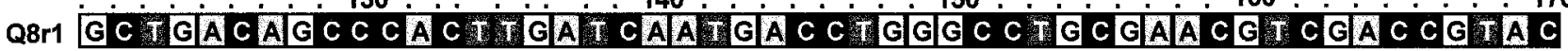

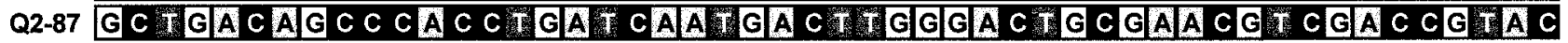

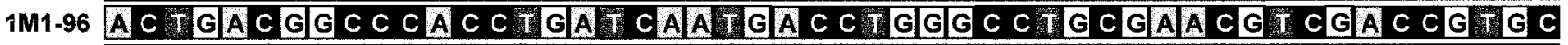

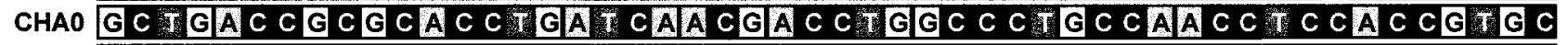

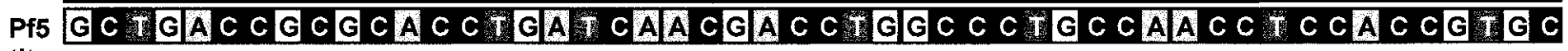
Identity

BPR3

500

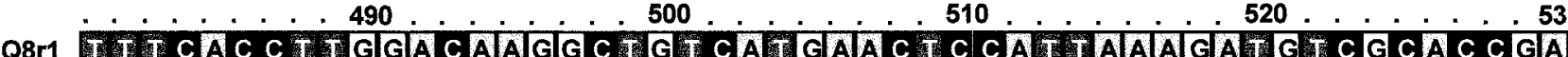

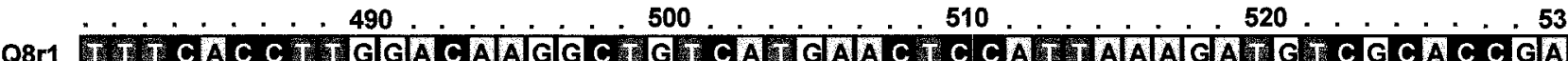

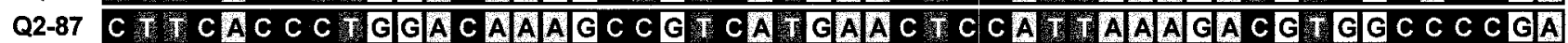

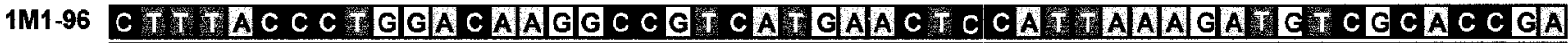

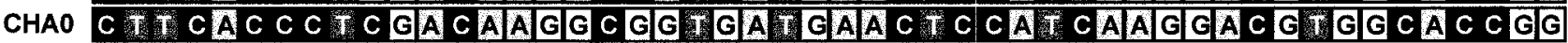

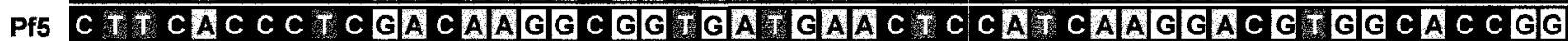
Identity

BPR2

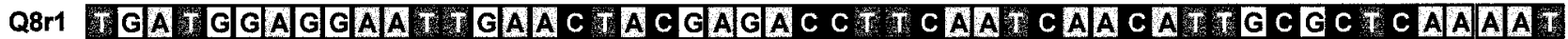

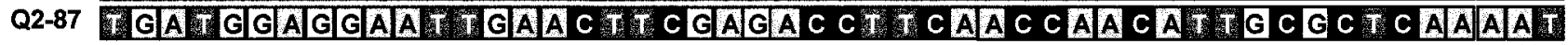

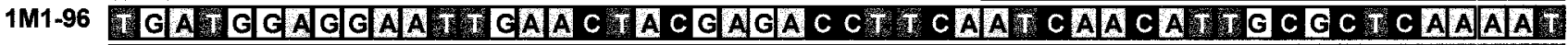

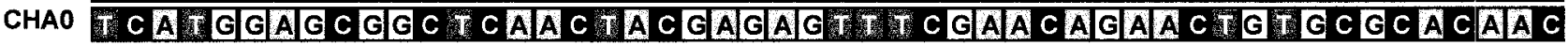

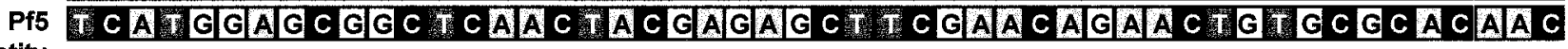

Identity : : : : : : :

\section{BPR4}

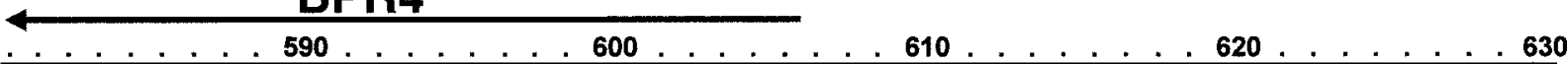

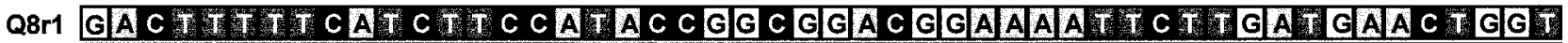

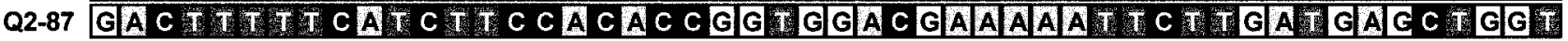

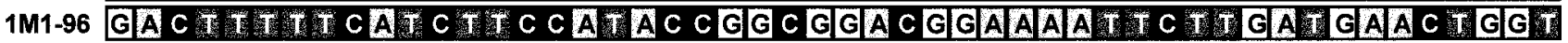

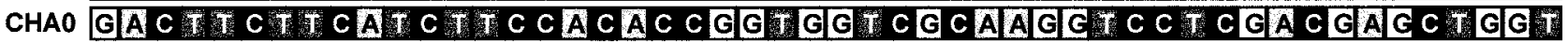

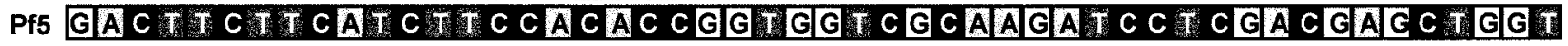

Identity : : : : : : : : : : : : : : : : : : : : : : : : : : : : : : : :

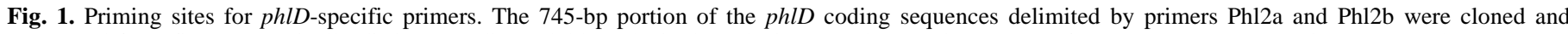

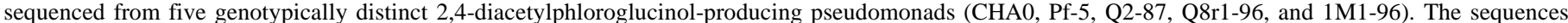

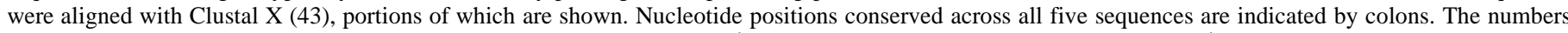

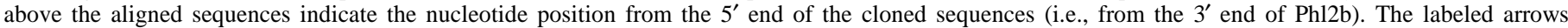
represent the newly designed primers and overlay the portions of the phlD gene to which they are predicted to anneal. 
Limit of detection of the assay. To determine the maximal limit of detection of the PCR-based assay with B2BF and BPR4, mixtures of $p h l D^{+}$(Q8r1-96 or Pf-5) and $p h l D^{-}$(2-79) strains were used as whole cell templates (described previously). In mixtures containing a fixed proportion of Q8r1-96 (4\% of the total), an average of only $\log 2.4 \mathrm{phlD}^{+}$cells per reaction was needed to give rise to clear amplification signals under standardized PCR conditions. In mixtures where the phlD $D^{+}$cells were present in a fixed background of $\log 6.0 \mathrm{phlD^{- }}$ cells per reaction, Q8r1-96 could still be detected easily when present at $\log 2.6$ cells or $\approx 0.04 \%$ of the total. With Pf-5 the assay was less efficient. In mixtures containing a fixed proportion of Pf-5 (4\% of the total), an average of log 3.1 cells per reaction was needed to give rise to a clear amplification signal, and $\log 3.8$ cells (or $0.6 \%$ of the total) were required for clear amplification in the reactions containing $\log 6.0 \mathrm{phlD^{- }}$ cells. Given the dilution scheme described for the rhizosphere samples, the theoretical limit of detection for the rhizosphere washes was calculated to be $\log 5.6$ cells per sample. By enriching for $p h l D^{+}$cells in $1 / 3 \times \mathrm{KMB}^{+++}$, the theoretical limit of detection was predicted to be reduced to $\log 2.6$ cells per sample, based on the dilution scheme described. Coincidentally, this was very close to the actual limits defined by the in vitro assays described above. Because of the significantly lower limit of detection predicted, natural populations of $p h l D^{+}$pseudomonads were enumerated based on dilution extinction of rhizosphere washes incubated for 2 days in $1 / 3 \times \mathrm{KMB}^{+++}$broth.

In situ detection of 2,4-DAPG-producing Pseudomonas spp. with B2BF and BPR4. The PCR-based assay was used to enumerate rhizosphere populations of $p h l D^{+}$Pseudomonas spp. from wheat plants grown at Lind, WA. The presence of a 629-bp DNA product in a reaction indicated the presence of $p h l D^{+}$bacteria in the dilution culture used as whole cell template for PCR amplification (Fig. 4). The dilution factor of the terminal dilution showing a positive amplification signal (e.g., dilutions 5, 3, 6, and 8 indicated by black arrows in Figure 4A, B, C, and D, respectively) was used to calculate the number of $p h l D^{+}$pseudomonads in the sample, unless a skip was observed in the dilution series (described below). Likewise the dilution factor of the terminal dilution showing positive growth $\left(\mathrm{OD}_{600 \mathrm{~nm}} \geq 0.05\right)$ was used to calculate the total number of pseudomonads (e.g., dilutions 9, 6, 10, and 10 indicated by white arrows in Figure $4 \mathrm{~A}, \mathrm{~B}, \mathrm{C}$, and D, respec- tively). This latter number was useful in determining the proportion of pseudomonads with the phlD gene. For the dilution series described, the formula for calculating population sizes was $150 \times$ $3^{n}$ for the $\mathrm{n}^{\text {th }}$ dilution in which a positive signal was observed. In samples where populations exceeded log $3.6 \mathrm{phlD}^{+}$cells per rhizosphere, inconsistent amplification was observed in the first dilution cultures of each series (dilutions $n=1$ and 2). This inhibition of the PCR-based detection in the initial dilution cultures, makes the practical limit of detection $\geq \log 3.1$ cells per rhizosphere.

To test the accuracy of the PCR-based assay, the populations of inoculated and indigenous $p h l D^{+}$pseudomonads were enumerated from field-grown plants. The number of rifampicin-resistant inoculant cells per rhizosphere was estimated by two different methods: growth on rifampicin-containing media and by the PCRbased assay. For individual rhizospheres, the population sizes of W2-6R detected by phlD-specific primers were quite similar to those determined by culturing in $1 / 3 \times \mathrm{KMBRif}^{+}$broth. The difference in the positive terminal dilution determined by the two separate methods was $\leq 2$ in $78 \%$ of the samples and $\leq 1$ in $61 \%$ of the samples. Therefore, the values obtained for individual rhizospheres can be considered point estimates of the true values accurate to approximately one order of magnitude, because we used a threefold dilution series. A minimum of eight independent rhizospheres was required to establish a direct correlation between the population sizes predicted by the two different methods (Fig. 5). Therefore, one would require a minimum of eight independent rhizospheres to make meaningful comparisons between treatments when using our assay. Over $97 \%$ of the rhizospheres sampled over the course of the growing season $(N=72)$ were colonized by the inoculant strain W2-6R when it was applied at log 4 cells per seed. The median population size of W2-6R was between $\log 4.3$ and $\log 6.7$ per rhizosphere and represented between 6.4 and $100 \%$ of the total pseudomonad population in each sample $(n=8)$. In contrast, only $28 \%$ of the rhizospheres developing from uninoculated seed showed detectable populations of $p h l D^{+}$pseudomonads over the course of the growing season $(N=72)$. These indigneous populations inhabited between 0 and $75 \%$ of the rhizospheres $(n=8)$ depending on the sampling date. In rhizospheres where they were detected, the indigenous populations ranged in size from $\log 3.8$ to $\log 4.6$ cells per rhizosphere and represented between 0.4 and $11 \%$ of the total pseudomonad population $(n=8)$.

TABLE 2. Most significant matches between $p h l D$ primers and nontarget sequences

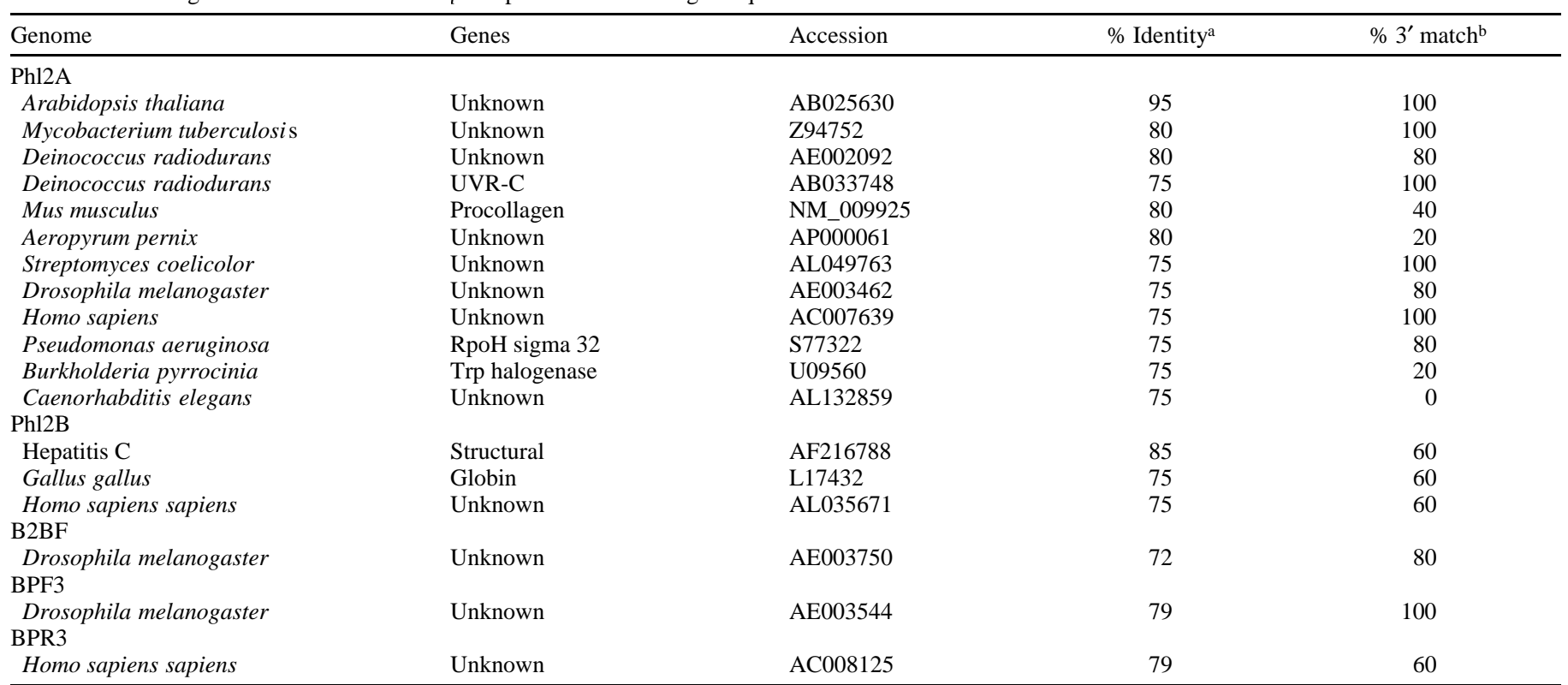

${ }^{a}$ Based on comparison of primer sequences to GenBank by Basic BLAST 2.0.12 (1). The percentage of nucleotides of the primer found in the database sequences listed are tabulated.

${ }^{\mathrm{b}}$ Identity of matching sequence to the five nucleotides at the 3 ' end of the primer. 
In approximately one-sixth of the dilution series, skips of one or two dilutions were observed before the terminal dilution, giving a positive signal. For example, in Figure 4A, a skip was observed between dilutions 3 and 5 in the PCR-based assay. The frequency of skips observed was not significantly different from that predicted by chance, given the dilution series described $\left(0.90>P\left(\chi^{2}\right)>\right.$ 0.10 ) (Table 3 ). Therefore, we deduced that the positive terminal dilution represented a single culture forming unit that had been transferred to a higher dilution. In such instances, the dilution factor corresponding to the initially skipped dilution was used to calculate the population size. For example, dilution 4 (indicated by a hatched arrow) was used to calculate the population size of phlD ${ }^{+}$pseudomonads for the sample shown in Figure 4A.

Use of RFLPs to characterize genotypic diversity. The 629-bp products amplified with $\mathrm{B} 2 \mathrm{BF}$ and BPR4 from a genotypically diverse set of 2,4-DAPG-producing Pseudomonas spp. were digested with six different restriction enzymes (Table 4). Fragments larger than $75 \mathrm{bp}$ were readily observed, sized ( $\pm 15 \mathrm{bp})$, and used to define each RFLP pattern. Between three and eight different RFLP patterns were revealed by each restriction enzyme tested (Table 4). As expected, the RFLP patterns for the phlD fragments amplified from CHA0, Pf-5, Q2-87, Q8r1-96, and 1M1-96 matched those predicted by computer-simulated digests of their cloned sequences (data not shown). The combination of all the
RFLP data revealed 13 groups that corresponded exactly to those defined previously by BOX-PCR genomic fingerprinting.

The combination of just three digests (i.e., those using HaeIII, TaqI, and MspI) was sufficient to discriminate between these 13 different groups. The restriction patterns indicative of the distinct genotypes defined previously by BOX-PCR are shown in Figure 6. Because digestion of the 629-bp product with HaeIII reveals the greatest number of easily discernible restriction patterns, a single digest using this enzyme should be used to initially define the genomic groups present in an individual sample. However, two restriction patterns (indicated by + or $*$ in Figure 6 ) generated with HaeIII can be indicative of more than one BOX-PCR genotype. In samples where these two patterns are observed, a separate test digest of the 629-bp phlD PCR product, with TaqI, can be used to determine which genotypically distinct populations are present. However, if the BOX G and/or $\mathrm{H}$ genotypes are present, a third digest, with $M s p I$, must be used to discriminate between them.

Restriction digests of the sequences amplified from the terminal dilution of a dilution series containing $p h l D^{+}$signals were used to define the genotype of the most abundant rhizosphere populations of 2,4-DAPG-producing Pseudomonas spp. The RFLP patterns displayed in Figure 6 were used as standards by which the genotype was determined. Only two genotypes were observed in the rhizosphere samples taken from Lind, WA (Fig. 7). The first was

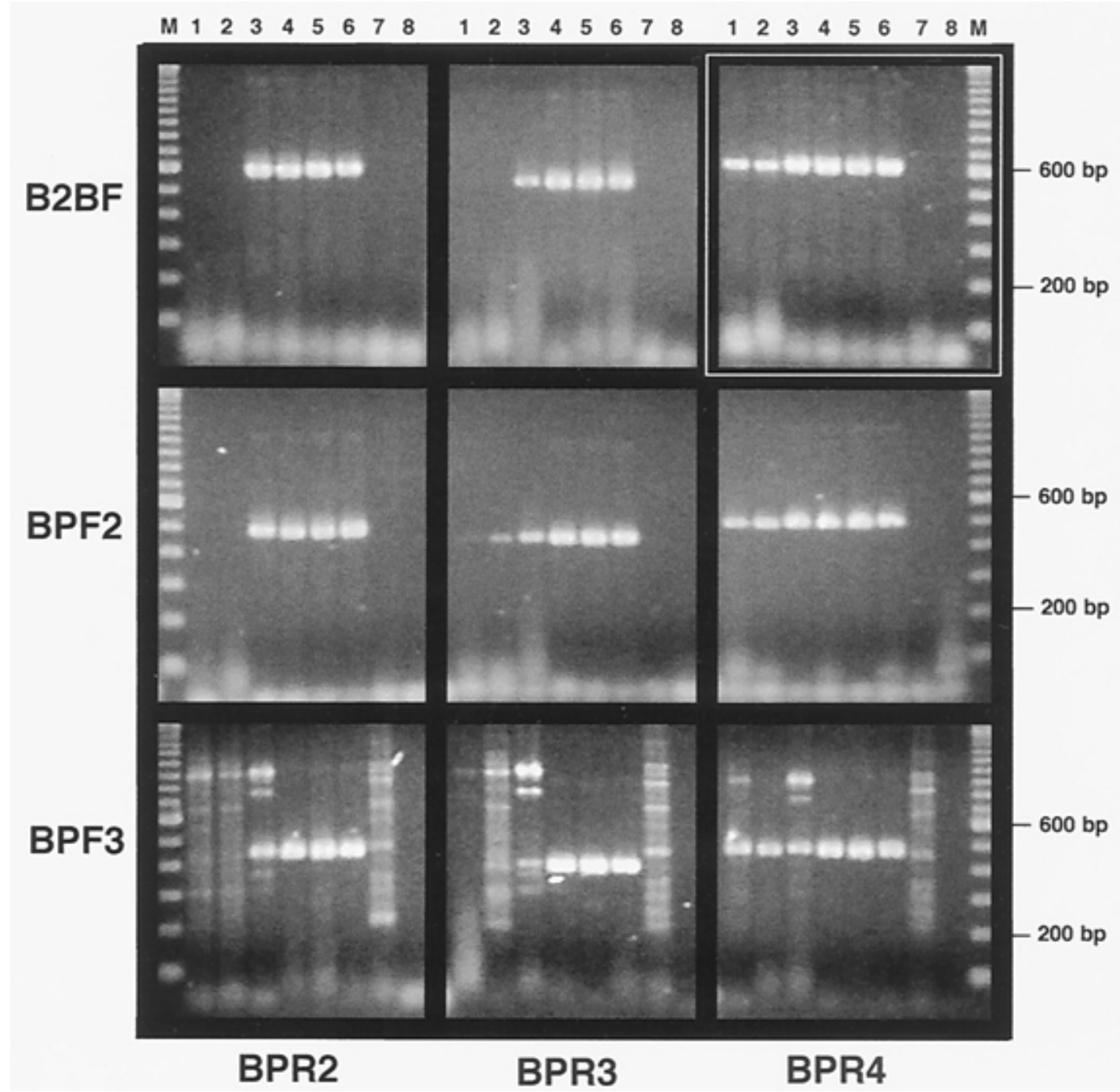

Fig. 2. Amplification of phlD sequences by polymerase chain reaction (PCR) with different primer combinations. Approximately $10^{6}$ cells per reaction of six different strains of $p h l D^{+}$fluorescent Pseudomonas spp. (lanes 1 through 6) were used as whole-cell templates for PCR amplification. One phlD ${ }^{-}$strain (lane 7 ) and cell-free reaction mix (lane 8) were used as negative controls. Strains used were: lane 1, CHA0; 2, Pf-5; 3, Q2-87; 4, Q8r1-96; 5, 1M1-96; 6, F113; and 7, 279. For each set of reactions, the forward and reverse primers are indicated along the vertical and horizontal axes, respectively. Amplification products were separated on $1.5 \%$ agarose gels and visualized by staining with ethidium bromide. A 100-bp DNA size standard (M) indicates the size of the amplified products. 
determined by HaeIII digests to correspond to the BOX D genotype, and the second was determined to be the BOX L genotype by two digests (HaeIII and TaqI). A third digest, with MspI, was not required for delineating the genotypes present in the Lind samples. In the large majority of rhizospheres, a single genotype was observed to predominate, although infrequent exceptions were noted. For example, in lane 7 of Figure 7, bands indicative of both the D and L genotypes can be observed. In the field plots where inoculated seed had been sown, the D genotype (the same as W2-6R) predominated in all samples as expected. Where noninoculated seed had been sown, the L genotype predominated in $70 \%$ of the rhizospheres, whereas the D genotype predominated in only $30 \%$ of the rhizospheres.

Recovery of $\boldsymbol{p h l D}^{+}$isolates. We attempted to isolate colonies of $p h l D^{+}$pseudomonads from the terminal dilutions from which $p h l D$ sequences had been amplified by streaking $50-\mu \mathrm{l}$ portions of the glycerol-containing replicate dilutions onto $1 / 3 \times \mathrm{KMB}^{+++}$agar. When the $p h l D^{+}$populations represented $\geq 3.7 \%$ of the total pseudomonad population, we found that we could generally recover representative isolates. In such instances, the genotypes of the recovered $p h l D^{+}$isolates were the same as those determined by RFLP analysis of the phlD sequences amplified from the mixed enrichment cultures.

\section{DISCUSSION}

We developed a rapid and reliable PCR-based assay for characterizing 2,4-DAPG-producing Pseudomonas populations based on the amplification of phlD gene sequences. The assay was used to quantify the abundance of $p h l D^{+}$pseudomonad populations and

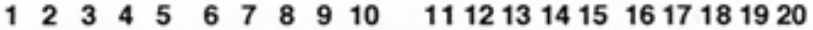

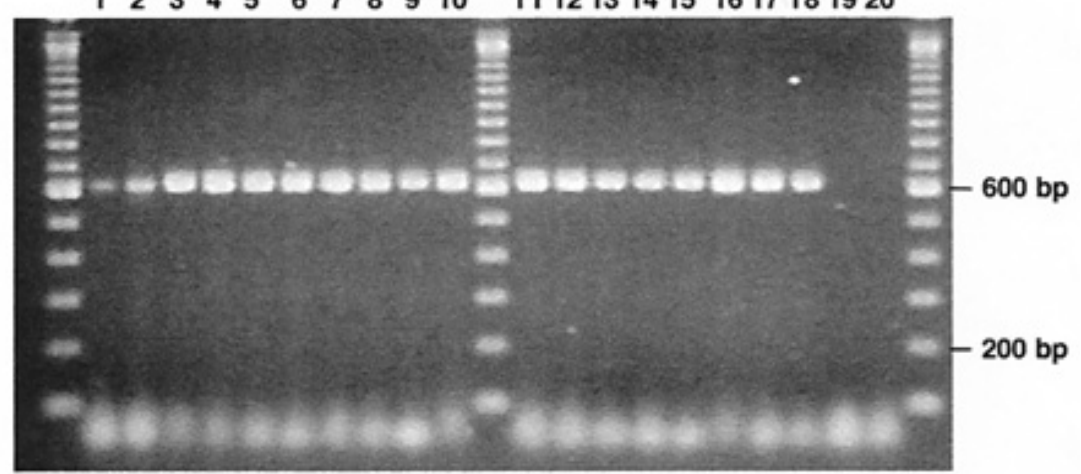

A A B D D D EF F G H I J K L M N

\section{BOX Genotype}

Fig. 3. Amplification of phlD gene sequences from genotypically distinct 2,4-diacetylphloroglucinol-producing Pseudomonas spp. with primers B2BF and BPR4. A 629-bp polymerase chain reaction (PCR) product was amplified from whole-cell templates prepared from a diverse set of phlD ${ }^{+}$Pseudomonas spp. (lanes 1 through 18) but not from a phlD $D^{-}$strain (lane 19) nor from cell-free reaction mix (lane 20). The genotypes of the 18 phlD strains, defined previously by BOX-PCR genomic fingerprinting (27), are indicated at the bottom of the figure. Strains were as follows: lane 1, CHA0; 2, Pf-5; 3, Q2-87; 4, Q8r1-96; 5, W2-6; 6, OC4-1; 7, FFL1R9; 8, Q2-2; 9, JMP6; 10, JMP7; 11, FFL1R18; 12, CV1-1; 13, FTAD1R36; 14, FFL1R22; 15, F113; 16; W4-4; 17, D27B1; 18, HT5-1; and 19, 2-79. Amplification products were separated on 1.5\% agarose gels and visualized by staining with ethidium bromide. A 100-bp DNA size standard (M) indicates the size of the amplified products.

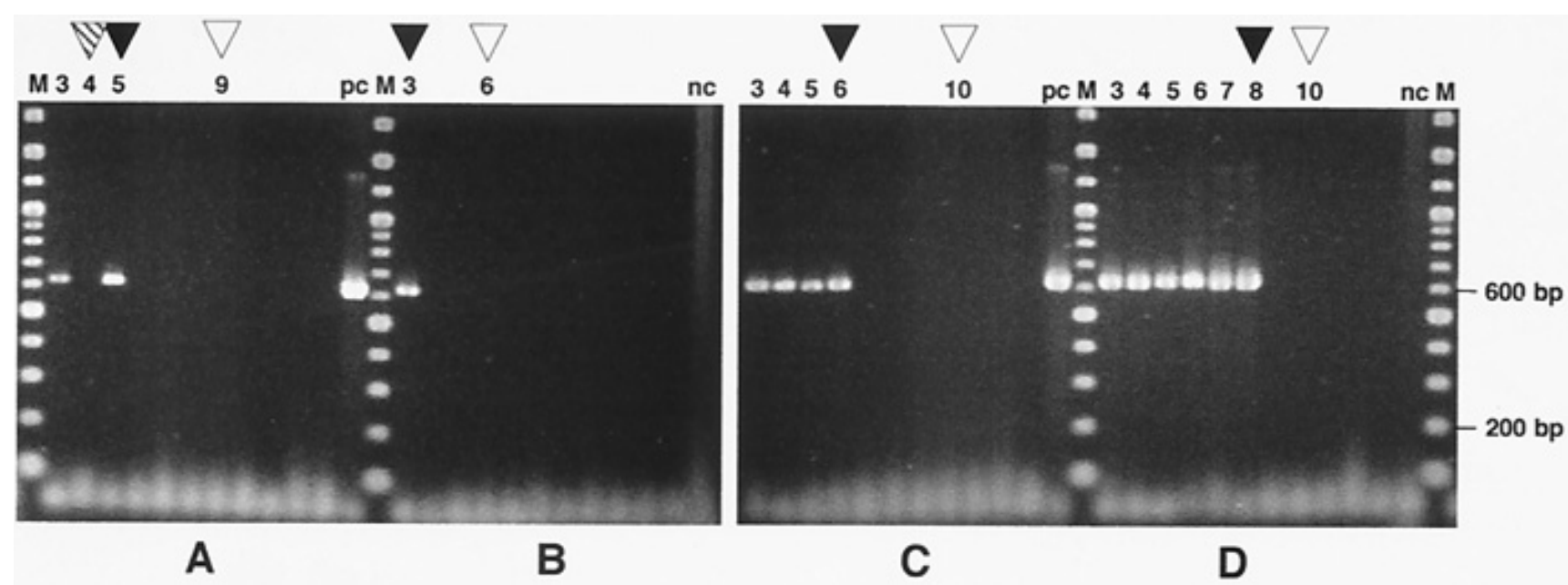

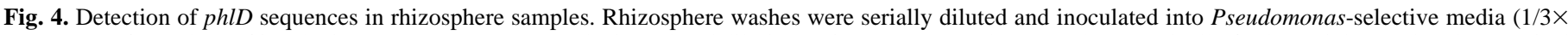

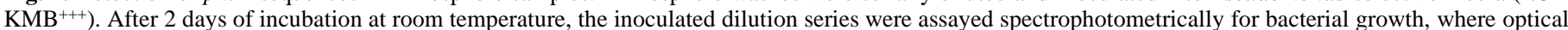

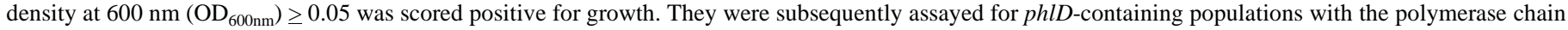

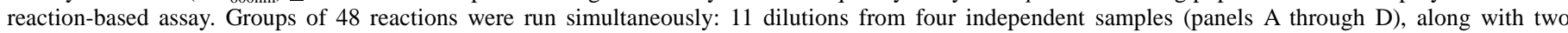

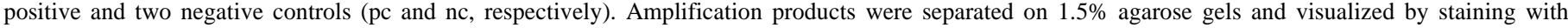

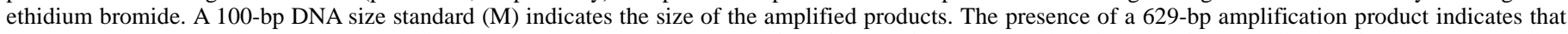

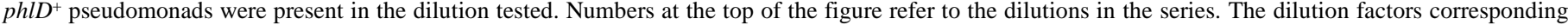

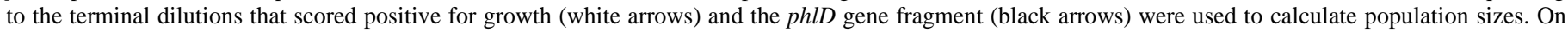

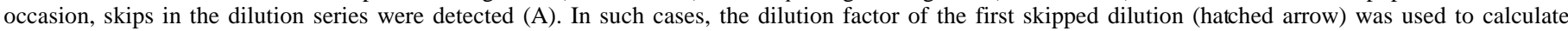
population size. 
to directly characterize the genotype of the most abundant $p h l D^{+}$ populations inhabiting the rhizosphere of wheat. This assay was a significant improvement over the colony hybridization protocol previously developed in our laboratory (37). The cost, in material and labor, was greatly reduced by using multiwell plates and an eight-channel multipipettor for preparing dilutions and PCR reactions. Up to 20 times as many samples per unit effort could be processed compared to the colony hybridization procedure, allowing us to make more detailed studies of the microbial ecology of the targeted bacterial populations. We also detected indigenous populations of $p h l D^{+}$pseudomonad populations more frequently with the PCR-based assay (B. McSpadden Gardener and D. Weller, unpublished data). By taking advantage of the correlation between phlD RFLP pattern and genomic fingerprint which was recently demonstrated in our laboratory (26), we were able to directly characterize the most abundant phlD ${ }^{+}$populations without isolating individual colonies. Because this correlation had been established with a significantly larger portion of the phlD gene (745 versus $629 \mathrm{bp}$ ), we first verified the results of Mavrodi et al. (26) using the 629-bp product amplified by B2BF and BPR4. Then, we screened the RFLP data to find the combination of digests that would most directly and rapidly identify the genotype as previously defined by BOX-PCR (28). Although more than one genotype may be present in the rhizosphere, we almost always detected a single genotype in any given sample. This is consistent with previous observations where generally only one genotype of 2,4DAPG-producing pseudomonad was isolated from any given rhizosphere sample (28). Even though the PCR-based assay detects $p h l D^{+}$pseudomonads in mixtures, we were still able to recover isolates by streaking out portions of the positive dilution cultures on $1 / 3 \times \mathrm{KMB}^{+++}$agar. This is quite useful because it allows one to rapidly screen samples for novel genotypes for further study.

Like all methods for studying the microbial ecology of natural environments, the PCR-based assay described has its limitations $(17,32)$. First, it relies on the growth of $p h l D^{+}$bacteria on liquid media. Although detection from rhizosphere washes was possible

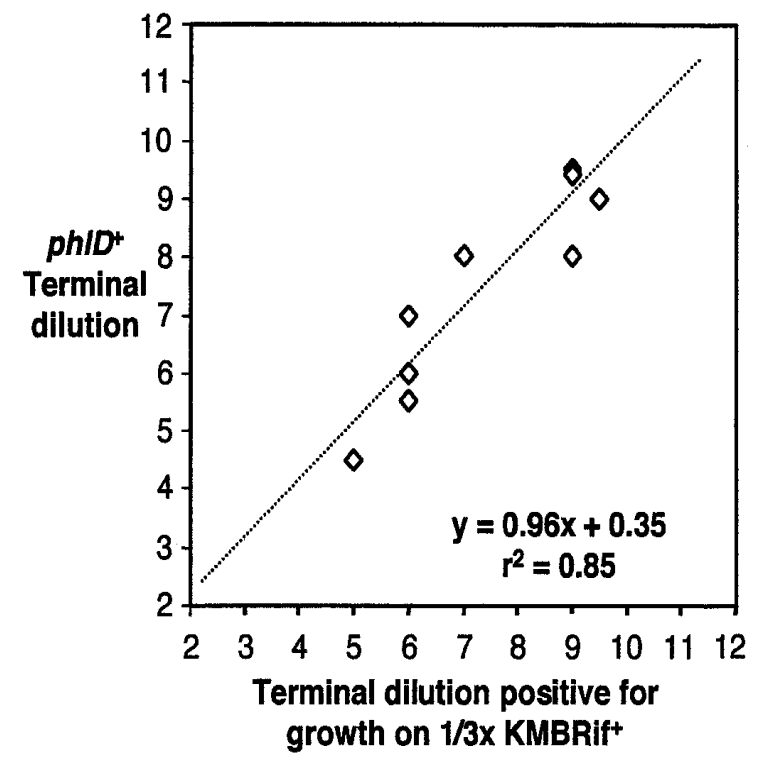

Fig. 5. Comparison of the population estimates of the inoculant strain, W2$6 \mathrm{R}$, determined by growth on rifampicin-containing media and by the phlDspecific polymerase chain reaction (PCR)-based assay. Populations of the $\mathrm{Rif}^{\mathrm{T}}$, phlD ${ }^{+}$strain (W2-6R), were enumerated by two different methods. Wheat seeds were treated with strain $\mathrm{W} 2-6 \mathrm{R}$ at a rate of $10^{4}$ bacteria per seed and planted at Lind, WA. Plants grown from these seeds were sampled between 4 and 19 weeks postplanting. Rhizosphere washes were serially diluted in sterile distilled water and inoculated into a Pseudomonas-selective media $\left(1 / 3 \times \mathrm{KMB}^{+++}\right)$for the PCR-based assay and $1 / 3 \times \mathrm{KMBRif}^{+}$for culturable counts. Median values $(n=8)$ for nine different samplings are plotted. (data not shown), the theoretical limit of detection was approximately $\log 5.6$ cells per rhizosphere, too high to be considered generally useful for studying population dynamics. Thus, the assay was generally performed with the additional step of incubating aliquots of the rhizosphere washes in $1 / 3 \times \mathrm{KMB}^{+++}$media that is selective for pseudomonads. It might be possible to detect fewer cells directly in rhizosphere washes by isolating the bacterial fraction away from other soil components, however, that would greatly increase the time it takes to process samples. Alternatively, the use of fluorescently-labeled primers (as in a "realtime" PCR application) could lower the limit of detection of the assay because less product would be required for detection in any given reaction. Nonetheless, direct detection at the level obtained in our assays may be useful considering that Raaijmakers et al. $(34,36)$ have suggested that a threshold level of $\log 5 \mathrm{phlD}^{+}$cells per gram of rhizosphere was required to achieve take-all suppression. To determine what fraction of the uncultured $p h l D^{+}$cells are metabolically active, it might be useful to combine our assay with a bromodeoxyuridine-labeling protocol, such as the one reported by Borneman (5). Another limitation of the assay is that it does not

TABLE 3. Fraction of rhizosphere samples with observed skips in the dilution series

\begin{tabular}{lccc}
\hline No. of skips & 0 & 1 & $>2$ \\
\hline Expected $^{\mathrm{a}}$ & 0.856 & 0.111 & 0.032 \\
Observed $^{\mathrm{b}}$ & & & \\
Cultures & $0.870(0.093)$ & $0.104(0.063)$ & $0.026(0.049)$ \\
phlD-PCR & $0.828(0.068)$ & $0.119(0.061)$ & $0.052(0.038)$ \\
\hline
\end{tabular}

a Predicted fraction of samples with the given number of skips based on random sampling error for the threefold dilution series used in the assay.

${ }^{\mathrm{b}}$ Fraction of rhizosphere samples with a given number of skips in the dilution series for a single sampling date $(n=24)$. Cultures refer to the dilution series of bacteria growing on a Pseudomonas selective medium (1/3X $\left.\mathrm{KMB}^{+++}\right)$to an optical density at $600 \mathrm{~nm}\left(\mathrm{OD}_{600 \mathrm{~nm}}\right) \geq 0.05$, and phlDpolymerase chain reaction (PCR) refers to the PCR-based assays in which a 629-bp phlD-specific amplification product was observed. The mean and standard deviation (in parentheses) of eight independent field samplings are shown.

TABLE 4. Genotypes of a diverse set of 2,4-diacetylphloroglucinolproducing Pseudomonas spp. determined by restriction fragment length polymorphism (RFLP) analysis of the 629-bp portion of the phlD gene amplified with B2BF and BPR4 as compared with those previously defined by BOXpolymerase chain reaction (PCR) genomic fingerprinting

\begin{tabular}{|c|c|c|c|c|c|c|c|c|}
\hline \multirow[b]{2}{*}{ Strain } & \multicolumn{6}{|c|}{ Restriction enzyme } & \multirow[b]{2}{*}{ Combined $^{\mathrm{a}}$} & \multirow[b]{2}{*}{$\mathrm{BOX}^{\mathrm{b}}$} \\
\hline & HaeIII & $\operatorname{Taq} \mathrm{I}$ & MspI & Sau96I & $R s a \mathrm{I}$ & HinfI & & \\
\hline CHA0 & A & A & A & A & A & A & A & A \\
\hline Pf5 & A & A & A & A & A & A & A & A \\
\hline Q2-87 & $\mathrm{B}$ & B & $\mathrm{B}$ & B & $\mathrm{B}$ & $\mathrm{B}$ & B & $\mathrm{B}$ \\
\hline Q8r1 & $\mathrm{D}$ & $\mathrm{D}$ & $\mathrm{D}$ & A & $\mathrm{B}$ & $\mathrm{C}$ & $\mathrm{D}$ & $\mathrm{D}$ \\
\hline W2-6 & $\mathrm{D}$ & $\mathrm{D}$ & $\mathrm{D}$ & A & $\mathrm{B}$ & $\mathrm{C}$ & $\mathrm{D}$ & $\mathrm{D}$ \\
\hline OC4-1 & $\mathrm{D}$ & $\mathrm{D}$ & $\mathrm{D}$ & A & $\mathrm{B}$ & $\mathrm{C}$ & $\mathrm{D}$ & $\mathrm{D}$ \\
\hline FFL1R9 & $\mathrm{D}$ & $\mathrm{D}$ & $\mathrm{D}$ & A & $\mathrm{B}$ & $\mathrm{C}$ & $\mathrm{D}$ & $\mathrm{D}$ \\
\hline Q2-2 & $\mathrm{E}$ & $\mathrm{D}$ & $\mathrm{E}$ & $\mathrm{C}$ & $\mathrm{B}$ & $\mathrm{C}$ & $\mathrm{E}$ & $\mathrm{E}$ \\
\hline JMP6 & $\mathrm{F}$ & $\mathrm{F}$ & $\mathrm{F}$ & $\mathrm{C}$ & B & $\mathrm{C}$ & $\mathrm{F}$ & $\mathrm{F}$ \\
\hline JMP7 & $\mathrm{F}$ & $\mathrm{F}$ & $\mathrm{F}$ & $\mathrm{C}$ & B & $\mathrm{C}$ & $\mathrm{F}$ & $\mathrm{F}$ \\
\hline FFL1R18 & G & G & $\mathrm{E}$ & $\mathrm{C}$ & $\mathrm{C}$ & $\mathrm{C}$ & G & G \\
\hline CV1-1 & G & $\mathrm{H}$ & $\mathrm{E}$ & $\mathrm{C}$ & $\mathrm{C}$ & $\mathrm{C}$ & $\mathrm{H}$ & $\mathrm{H}$ \\
\hline FTAD1R36 & $\mathrm{H}$ & I & D & A & B & $\mathrm{C}$ & I & I \\
\hline FFL1R22 & G & $\mathrm{G}$ & D & $\mathrm{C}$ & B & $\mathrm{C}$ & $\mathrm{J}$ & $\mathrm{J}$ \\
\hline F113 & $\mathrm{F}$ & $\mathrm{F}$ & D & $\mathrm{C}$ & B & $\mathrm{C}$ & $\mathrm{K}$ & $\mathrm{K}$ \\
\hline W4-4 & $\mathrm{G}$ & $\mathrm{D}$ & $\mathrm{G}$ & $\mathrm{C}$ & $\mathrm{D}$ & $\mathrm{C}$ & $\mathrm{L}$ & $\mathrm{L}$ \\
\hline D27B1 & I & $\mathrm{F}$ & $\mathrm{D}$ & $\mathrm{D}$ & B & $\mathrm{C}$ & M & M \\
\hline HT5-1 & $\mathrm{G}$ & $\mathrm{J}$ & $\mathrm{F}$ & $\mathrm{C}$ & B & $\mathrm{C}$ & $\mathrm{N}$ & $\mathrm{N}$ \\
\hline $\mathrm{N}^{\mathrm{c}}$ & 8 & 8 & 6 & 4 & 4 & 3 & 13 & 13 \\
\hline
\end{tabular}

a Genotype defined by considering all of the RFLP patterns generated with the six different restriction enzymes.

b Genotypes defined by BOX-PCR genomic fingerprinting (28).

c The total number of genotypes distinguished. 
directly address the relative activity of the phl biosynthetic locus in the populations characterized. Although it has been reported that the amount of 2,4-DAPG produced in the rhizosphere is proportional to the abundance of $p h l D^{+}$strains in wheat rhizospheres grown under controlled conditions (34), it seems likely that the amount of antibiotic produced in any given rhizosphere will depend on a variety of environmental factors present in that environment (i.e., moisture, temperature, $\mathrm{pH}$, and the presence of antagonistic or synergistic co-inhabitants). Production of 2,4-DAPG in vitro has been reported to vary among strains $(15,39)$, so the level of disease protection may differ depending on the genotype of the most abundant $p h l D^{+}$strain present in the rhizosphere. Additionally, the correlation between population size and disease suppressiveness might not hold in some cases, i.e., when the biosynthetic operon containing the phlD sequences detected is incomplete or nonfunctional. However, we think that such a loss of function will likely be the exception to the rule. Although global regulatory mutants lacking the ability to produce $2,4-\mathrm{DAPG}(10$, 19) could appear spontaneously, we are unaware of any reports of

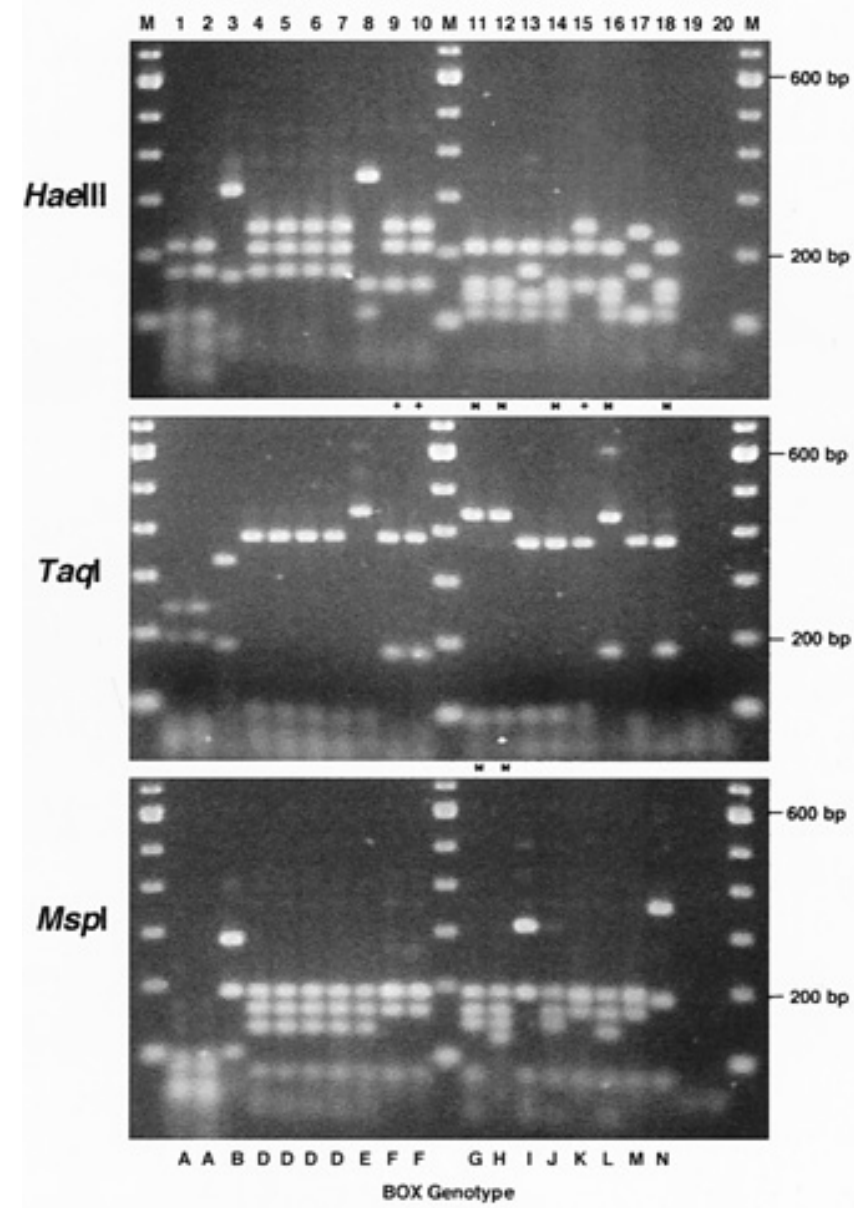

Fig. 6. Determination of the genotype of 2,4-diacetylphloroglucinolproducing Pseudomonas spp. by restriction fragment length polymorphism (RFLP) analysis of phlD sequences amplified with B2BF and BPR4. The 629-bp of the phlD gene amplified by B2BF and BPR4 was digested sequentially with HaeIII, TaqI, or MspI. RFLPs detected by these three enzymes were sufficient to distinguish all 13 genotypes previously defined by BOX polymerase chain reaction (PCR) genomic fingerprinting (28). Amplification products were separated on $1.5 \%$ agarose gels and visualized by staining with ethidium bromide. A 100-bp DNA size standard (M) indicates the size of the amplified products. Restriction patterns generated with Hae III or HaeIII and TaqI that correspond to multiple genotypes are indicated $(+$ and $*$ ) below the corresponding samples. Cells used as templates for the PCR-based assay were as follows: lane 1, CHA0; 2, Pf-5; 3, Q2-87; 4, Q8r196; 5, W2-6; 6, OC4-1; 7, FFL1R9; 8, Q2-2; 9, JMP6; 10, JMP7; 11, FFL1R18; 12, CV1-1; 13, FTAD1R36; 14, FFL1R22; 15, F113; 16, W4-4; 17, D27B1; 18, HT5-1; 19, 2-79; and 20, none. the occurrence of such mutants in natural systems. In contrast, all of the $p h l D^{+}$pseudomonad strains described so far have been reported to produce significant quantities of 2,4-DAPG in vitro $(12,15,30,39)$.

The assay described is useful for studying both indigenous as well as inoculant $p h l D^{+}$bacteria. Although a variety of molecular and phenotypic markers have been used to study the ecology of microbial isolates $(3,11,17)$, there is some concern that the marked strains do not behave similarly to the wild-type strains without selectable markers $(22,24)$. Therefore, characterizing indigenous populations of subject microorganisms would be preferable. Whereas much is known about the biocontrol abilities of 2,4DAPG-producing fluorescent Pseudomonas spp. when applied as seed or soil inoculants $(9,15,30,34,36,39)$, less is known about the ecological importance of natural populations of these bacteria in agro-ecosystems. The abundance of 2,4-DAPG producers has been correlated with take-all suppressiveness in several Pacific Northwest take-all decline soils (34-37), but direct evidence from field studies for the concurrent increase of $p h l D^{+}$populations and natural soil suppressiveness to root disease is still needed. We are currently using the method described in this study to develop detailed descriptions of the rhizosphere population dynamics of

$$
123 * 45678 * 910 * 11 * 1213
$$
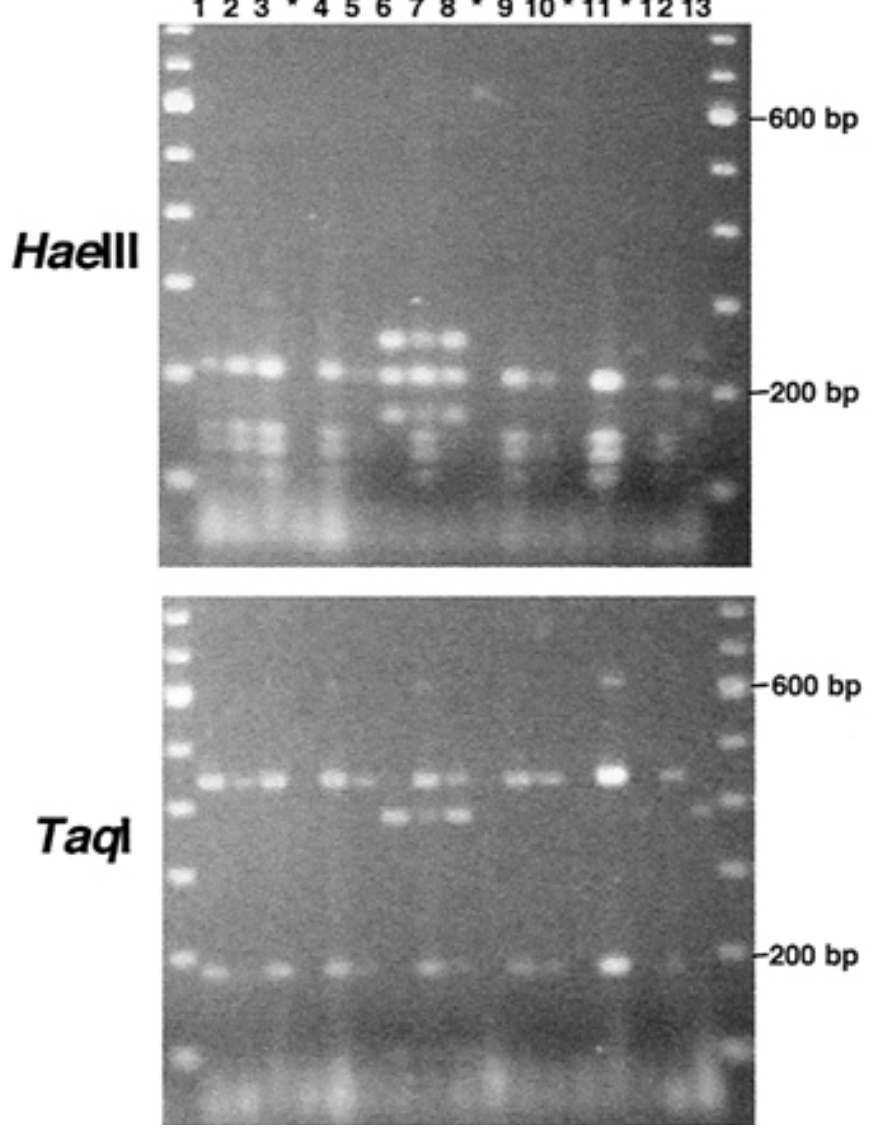

Fig. 7. Direct characterization of the most abundant $p h l D^{+}$genotypes present in rhizosphere samples. Rhizospheres of wheat plants grown at Lind, WA were assayed for phlD-containing fluorescent Pseudomonas spp. by using the polymerase chain reaction (PCR)-based assay. When a 629-bp amplification product was observed, an aliquot of the terminal phlD ${ }^{+}$PCR reaction was digested with HaeIII or TaqI. Digested fragments were separated on 2\% agarose gels and visualized by staining with ethidium bromide. A 100-bp DNA size standard (M) indicates the size of the amplified products. The restriction patterns obtained from 13 individual rhizospheres harboring $p h l D^{+}$ pseudomonads (1 through 13) are shown, along with several negative control reactions $(*)$. Such patterns were compared with those displayed in Figure 6 to determine the genotypes present in each sample. In this case, only the D genotype (samples 6 through 8) and the L genotype (samples 1 through 5, 7, and 9 through 13) were observed to inhabit the rhizosphere of wheat plants grown at Lind, WA. 
2,4-DAPG-producing fluorescent Pseudomonas spp. in the field to determine the correlation of their abundance with changes in takeall suppressiveness in various crop rotations.

This study describes a protocol that can be adapted to study other microorganisms for which molecular markers exist. By analogy, it is obvious to apply our approach to develop assays targeting the biosynthetic genes of other antifungal metabolites. In fact, the genes required for the biosynthesis of phenazines, pyrrolnitrin, and pyoluteorin have been cloned and sequenced from a variety of fluorescent Pseudomonas spp. $(16,25,29)$, and we have begun to develop an analogous assay for bacteria that produce phenazines (B. McSpadden Gardener, D. Mavrodi, L. Thomashow, and D. Weller, unpublished data). Alternatively, genes involved in pathogenesis or virulence (e.g., avr and hrp genes) (20,21) may be targeted. With such assays, the population dynamics of different ecological groups (i.e., beneficial and pathogenic microorganisms) could be studied in greater detail. Ultimately, this may lead to the development of more effective and ecologically sound applications of biological control of plant pathogens.

\section{ACKNOWLEDGMENTS}

This research was supported by grant 97-35107-4804 from the U.S. Department of Agriculture, National Research Initiative, Competitive Grants Program. We thank C. Merrit and C. E. Sachs for their technical assistance.

\section{LITERATURE CITED}

1. Altschul, S. F., Madden, T. L., Schiffer, A. A., Zhang, J., Zhang, Z., Miller, W., and Lipman, D. J. 1997. Gapped BLAST and PSI-BLAST: A new generation of protein database search programs. Nucleic Acids Res. 25:3389-3402.

2. Ausubel, F. M., Brent, R., Kingstons, R. E., Moore, D. D., Seidman, J. G., Smith, J. A., and Struhl, K. (ed.). 1995. Short Protocols in Molecular Biology. John Wiley \& Sons, New York.

3. Bae, Y.-S., and Knudsen, G. R. 2000. Cotransformation of Trichoderma harzianum with $\beta$-glucuronidase and green fluorescent protein genes provides a useful tool for monitoring fungal growth and activity in natural soils. Appl. Environ. Microbiol. 66:810-815.

4. Bangera, M. G., and Thomashow, L. S. 1999. Identification and characterization of a gene cluster for synthesis of the polyketides antibiotic 2,4-diacetylphloroglucinol from Pseudomonas fluorescens Q2-87. J. Bacteriol. 181:3155-3163.

5. Borneman, J. 1999. Culture-independent identification of microorganisms that respond to specific soil stimuli. Appl. Environ. Microbiol. 65:3398-3400.

6. Cook, R. J., Thomashow, L. S., Weller, D. M., Fujimoto, D., Mazzola, M., Bangera, G., and Kim, D.-S. 1995. Molecular mechanisms of defense by rhizobacteria against root disease. Proc. Natl. Acad. Sci. USA 92:4197-4201.

7. Duffy, B. K., and Défago, G. 1997. Zinc improves biocontrol of Fusarium crown and root rot of tomato by Pseudomonas fluorescens and represses the production of pathogen metabolites inhibitory to bacterial antibiotic biosynthesis. Phytopathology 87:1250-1257.

8. Edel, V., and Alabouvette, C. 1996. Evaluation of restriction analysis of polymerase chain reaction (PCR)-amplified ribosomal DNA for the identification of Fusarium species. Mycol. Res. 101:179-187.

9. Fenton, A. M., Stephens, P. M., Crowley, J., O'Callaghan, M., and O'Gara, F. 1992. Exploitation of genes involved in 2,4-diacetylphloroglucinol biosynthesis to confer a new biocontrol capability to a Pseudomonas strain. Appl. Environ. Microbiol. 58:3873-3878.

10. Gaffney, T. D., Lam, S. T., Ligon, J., Gates, K., Frazelle, A., Di Maio, J., Hill, S., Goodwin, S., Torkewitz, N., Allshouse, A. M., Kempf, H.-J., and Becker, J. O. 1994. Global regulation of expression of antifungal factors by a Pseudomonas fluorescens biological control strain. Mol. Plant-Microbe Interact. 7:455-463.

11. Hagedorn, C. 1994. Spontaneous and intrinsic antibiotic resistance markers. Pages 575-591 in: Methods of Soil Analysis, Part 2. Microbiological and Biochemical Properties. Soil Sci. Soc. Am. Book Ser. 5.

12. Harrison, L. A., Letendre, L., Kovacevich, P., Pierson, E., and Weller, D. M. 1993. Purification of an antibiotic effective against Gaumannomyces graminis var. tritici produced by a biocontrol agent, Pseudomonas aureofaciens. Soil Biol. Biochem. 25:215-221.

13. Kageyama, K., Ohyama, A., and Hyakumachi, M. 1997. Detection of
Pythium ultimum using polymerase chain reaction with species-specific primers. Plant Dis. 81:1155-1160.

14. Keel, C., Weller, D. M., Natsch, A., Défago, G., Cook, R. J., and Thomashow, L. S. 1996. Conservation of the 2,4-diacetylphloroglucinol biosynthesis locus among fluorescent Pseudomonas strains from diverse geographic locations. Appl. Environ. Microbiol. 62:552-556.

15. Keel, C., Schnider, U., Maurhofer, M., Voisard, C., Laville, J., Burger, U., Wirthner, P., Haas, D., and Défago, G. 1992. Suppression of root diseases by Pseudomonas fluorescens CHA0: Importance of the bacterial secondary metabolite 2,4-diacetylphloroglucinol. Mol. Plant-Microbe Interact. 5:4-13.

16. Kirner, S., Hammer, P. E., Hill, D. S., Altmann, A., Fisher, I., Weislo, L. J., Lanahan, M., van Pee, K.-H., and Ligon, J. M. 1998. Functions encoded by pyrrolnitrin biosynthetic genes from Pseudomonas fluorescens. J. Bacteriol. 180:1939-1943.

17. Kluepfel, D. A. 1993. The behavior and tracking of bacteria in the rhizosphere. Annu. Rev. Phytopathol. 31:441-472.

18. Laguerre, G., Allard, M.-R., Revoy, F., and Amarger, N. 1994. Rapid identification of rhizobia by restriction fragment length polymorphism analysis of PCR-amplified 16S rRNA genes. Appl. Environ. Microbiol. 60:56-63.

19. Laville, J., Voisard, C., Keel, C., Maurhofer, M., Défago, G., and Haas, D. 1992. Global control in Pseudomonas fluorescens antibiotic synthesis and suppression of black root rot of tobacco. Proc. Natl. Acad. Sci. USA 89:1562-1566.

20. Leach, J. E., and White, F. F. 1996. Bacterial avirulence genes. Ann. Rev. Phytopathol. 34:153-179.

21. Lindgren, P. B. 1997. The role of hrp genes during plant-bacterial interactions. 35:129-152.

22. Lo, C.-T., Nelson, E. B., Hayes, C. K., and Harman, G. E. 1998. Ecological studies of transformed Trichoderma harzianum strain 1295-22 in the rhizosphere and on the phylloplane of creeping bentgrass. Phytopathology 88:129-136.

23. Louws, F. L., Rademaker, J. L. W., and deBruijn, F. J. 1999. The three Ds of PCR-based genomic analysis of phytobacteria: Diversity, detection, and disease diagnosis. Ann. Rev. Phytopathol. 37:81-125.

24. Mahaffee, W. F., Bauske, E. M., van Vuurde, J. W. L., van der Wolf, J. M., van den Brink, M., and Kloepper, J. W. 1997. Comparative analysis of antibiotic resistance, immunofluorescent colony staining, and a transgenic marker (bioluminescence) for monitoring the environmental fate of a rhizobacterium. Appl. Environ. Microbiol. 63:1617-1622.

25. Mavrodi, D. V., Ksenzenko, V. N., Bonsall, R. F., Cook, R. J., Boronin, A. M., and Thomashow, L. S. 1998. A seven-gene locus for synthesis of phenazine-1-carboxylic acid by Pseudomonas fluorescens 2-79. J. Bacteriol. 180:2541-2548.

26. Mavrodi, O. V., McSpadden Gardener, B. B., Mavrodi, D. V., Bonsall, R. F., Weller, D. M., and Thomashow, L. S. 2001. Genetic diversity of phlD from 2,4-diacetylphloroglucinol-producing fluorescent Pseudomonas spp. Phytopathology 91:35-43.

27. McSpadden Gardener, B., and Lilley, A. K. 1997. Application of common statistical tools. Pages 501-524 in: Modern Soil Microbiology. J. D. van Elsas, J. Trevors, and M. Wexler, eds. Marcel Dekker Inc., New York.

28. McSpadden Gardener, B., Schroeder, K., Kalloger, S., Raaijmakers, J., Thomashow, L. S., and Weller, D. M. 2000. Genotypic and phenotypic diversity of phlD-containing Pseudomonas isolated from the rhizosphere of wheat. Appl. Environ. Microbiol. 66:1939-1946.

29. Nowak-Thompson, B., Chaney, N., Wing, J. S., Gould, S. J., and Loper, J. E. 1999. Characterization of the pyoluteorin biosynthetic gene cluster of Pseudomonas fluorescens Pf-5. J. Bacteriol. 181:2166-2174.

30. Nowak-Thompson, B., Gould, S. J., Kraus, J., and Loper, J. E. 1994. Production of 2,4-diacetylphloroglucinol by the biocontrol agent Pseudomonas fluorescens Pf-5. Can. J. Microbiol. 40:1064-1066.

31. Pace, N. R. 1997. A molecular view of microbial diversity and the biosphere. Science 276:734-740.

32. Pepper, I. L. 1997. PCR: Applications for plant and soil microbes. Pages 437-444 in: Manual of Environmental Microbiology. G. R. Knudsen, M. J. McInerney, L. D. Stetzenbach, M. V. Walter, eds. American Society for Microbiology, Washington, D.C.

33. Picard, C., Di Cello, F., Ventura, M., Fani, R., and Guckert, A. 2000. Frequency and biodiversity of 2,4-diacetylphloroglucinol-producing bacteria isolated from the maize rhizosphere at different stages of plant growth. Appl. Environ. Microbiol. 66:948-955.

34. Raaijmakers, J., Bonsall, R. F., and Weller, D. M. 1999. Effect of population density of Pseudomonas fluorescens on production of 2,4-diacetylphloroglucinol in the rhizosphere of wheat. Phytopathology 89:470-475.

35. Raaijmakers, J., Hayes, K., Thomashow, L. S., and Weller, D. M. 1999. Diversity and rhizosphere competence of 2,4-diacetylphloroglucinolproducing Pseudomonas strains. (Abstr.) Phytopathology 89(suppl.):S63.

36. Raaijmakers, J., and Weller, D. M. 1998. Natural plant protection by 2,4diacetylphloroglucinol-producing Pseudomonas spp. in take-all decline 
soils. Mol. Plant-Microbe Interact. 11:144-152.

37. Raaijmakers, J., Weller, D. M., and Thomashow, L. S. 1997. Frequency of antibiotic-producing Pseudomonas spp. in natural environments. Appl. Environ. Microbiol. 63:881-887.

38. Shanahan, P., Glennon, J. D., Crowley, J. J., Donnelly, D. F., and O'Gara, F. 1992. Isolation of 2,4-diacetylphloroglucinol from a fluorescent pseudomonad and investigation of physiological parameters influencing its production. Appl. Environ. Microbiol. 58:353-358.

39. Sharifi-Tehrani, A., Zala, M., Natsch, A., Moenne-Loccoz, Y., and Défago, G. 1998. Biocontrol of soil-borne fungal plant diseases by 2,4diacetylphloroglucinol-producing fluorescent pseudomonads with different restriction profiles of amplified 16S rDNA. Eur. J. Plant Pathol. 104:631-643.

40. Sheskin, D. J. 1997. Handbook of Parametric and Nonparametric Statistical Procedures. CRC Press, Boca Raton, FL.

41. Simon, A., and Ridge, E. H. 1974. The use of ampicillin in a simplified selective medium for the isolation of fluorescent pseudomonads. J. Appl. Bacteriol. 37:459-460.
42. Stutz, E., Défago, G., and Kern, H. 1986. Naturally occurring fluorescent pseudomonads involved in suppression of black root rot of tobacco. Phytopathology 76:181-185.

43. Thompson, J. D., Gibson, T. J., Plewniak, F., Jeanmougin, F., and Higgins, D. G. 1997. The Clustal X windows interface: Flexible strategies for multiple sequence alignment aided by quality analysis tools. Nucleic Acids Res. 25:4876-4882.

44. Vincent, M. N., Harrison, L. A., Brackin, J. M., Kovacevich, P. A., Mukerji, P., Weller, D. M., and Pierson, E. A. 1991. Genetic analysis of the antifungal activity of a soilborne Pseudomonas aureofaciens strain. Appl. Environ. Microbiol. 57:2928-2934.

45. Weller, D. M., and Cook, R. J. 1983. Suppression of take-all on wheat by seed treatment with fluorescent pseudomonads. Phytopathology 73:463469.

46. Widmer, F., Seidler, R. J., Gillevet, P. M., Watrud, L. S., and Di Giovanni, G. D. 1998. A highly selective PCR protocol for detecting 16S rRNA genes of the genus Pseudomonas (sensu stricto) in environmental samples. Appl. Environ. Microbiol. 64:2545-2553. 